\title{
OMENSALIDADE E ANTROPOFAGIA COMO METÁFORAS DE PODER, VIOLÊNCIA E CONFLITOS NA ÁFricA SUBSAARIANA ${ }^{1}$
}

Daniela Calvo

Universidade do Estado do Rio de Janeiro

Rio de Janeiro - RJ - Brasil

Orcid: https://orcid.org/0000-0002-3936-1976

\section{Introdução}

Comer - comer algo ou comer alguém - é uma imagem poderosa para pensar poder, sofrimento, violência, medos e conflitos nos Estados pós-coloniais da África Subsaariana, já que representa um imaginário de predação constitutivo da vida cotidiana e da cosmopolítica. $\mathrm{O}$ ato de comer expressa-se em diferentes formas: na estética centrada no luxo e no corpo, empregada pelos Estados pós-coloniais para afirmar seu poder; no plano do imaginário, povoado por imagens de órgãos comidos, esvaziados de sua energia vital por feiticeiros durante o sono, e em mutilações e assassinatos com o intuito de produzir "medicinas" e amuletos.

A feitiçaria é um discurso que molda o poder, a riqueza, as desigualdades, as fortes mudanças, o sofrimento, a doença, os conflitos, a desordem, e que reconecta imaginários diferentes, mas interdependentes e em permanente tensão. Patrice Yengo (2016:11) ressalta que: "Mais do que antes, talvez, o princípio da feitiçaria se impõe socialmente e culturalmente, em particular como lógica estruturante das representações da anomia, do infortúnio e da precariedade".

A eficácia das imagens de riqueza e de comensalidade propostas pelas elites político-administrativas, econômicas e militares explica-se também pelo desejo do 
povo, num contexto marcado pela escassez e pela pobreza, e liga-se a regimes particulares de morte, remetendo à bruxaria, à noite, ao invisível". "Comer" é empoderar-se da energia vital do outro e servir-se de seu corpo para crescer a própria força e adquirir poder, sucesso, dinheiro, inteligência.

O discurso e a estética centrados no corpo e na comensalidade mostramse particularmente eficazes e poderosos, já que envolvem toda a população e são estruturantes da vida cotidiana. O Estado traça sua imagem e afirma seu poder, desenhando sua estética e colonizando o imaginário por meio de uma performatividade que mostra magnificência e prodigalidade em ricos banquetes, cerimônias e atos ritualizados. O Estado adquire o estatuto de "fetiche" (algo que é, ao mesmo tempo, "objetificado", tangível, e carregado de poder, sacralizado). A população é obrigada a participar, mas não se deixa "sujeitar" totalmente: entra no jogo e aceita a linguagem imposta pelo poder, mas não se integra da forma esperada, já que remodela e reverte esse discurso com piadas, paródias e jogos de palavras.

Achille Mbembe (2006) interpreta essas representações do Estado e suas ridicularizações como uma forma de estratégia, jogo do qual participam pessoas comuns e representantes do Estado de modo a tornar o poder cotidiano, rotineiro e familiar e, portanto, compreensível.

A tensão entre discursos públicos e a circulação de fofocas e piadas resulta num "desempoderamento", num esvaziamento mútuo do Estado e da população, numa "zombificação": "Esta 'zombificação' significa que cada um roubou do outro sua vitalidade, deixando ambos impotentes [impouvoir]" (Mbembe 2006:382).

Jean-François Bayart (1989) observa que comer significa nutrir-se, pois assume uma valência particular numa economia marcada pela escassez, mas é também acumular, explorar, atacar ou matar mediante a feitiçaria. E acrescenta Yengo:

De fato, além das numerosas variantes que definem a feitiçaria na África, uma constante aparece, aquela da antropofagia imaginária, em que o feiticeiro devora (ku-dia) a força vital da vítima. [...] Essa oculta uma outra, fundamental, que deve ser conectada à família, sua origem primeira. Todas as atividades feiticeiras implicam possuir o órgão do kundu no próprio ventre $(\operatorname{moyo})$, mas toda possessão de kundu não torna seu dono um ser antissocial. (Yengo 2016:41) .

Yengo (2016) defende que se deve falar de permanência e continuidade da feitiçaria na África Central, e não de retradicionalização, e que, na base do aumento de sua violência, está a crise que afeta sua estrutura de base: o parentesco (na desorganização das famílias e das linhagens e no enfraquecimento das estruturas tradicionais de autoridade), em que se adicionam novas hierarquias baseadas no conhecimento veiculado pelos colonizadores, no dinheiro e na mercadoria ${ }^{6}$. 
O autor observa também que a feitiçaria e o capitalismo se sustentam reciprocamente, pois pertencem ao mesmo registro: aquele da dominação, da reificação e do fetichismo. De fato, o mundo da feitiçaria engloba objetos e símbolos modernos (aviões, caminhões, telefones etc.), que, por sua vez, são carregados de poder místico e se tornam "fetiches".

A proliferação da feitiçaria e do "imaginário do oculto" está em continuidade com práticas e crenças tradicionais e com o trauma da colonização, que trouxe consigo uma violência estrutural intrínseca nas desigualdades e no exercício do poder? modela e reconecta de forma criativa imaginários diferentes, mas interdependentes e em permanente tensão e participa à dinâmica das relações de poder, conflitos, interesses e alianças, num campo heterogêneo e em constante mudança.

Segundo Florence Bernault (2006), os colonizadores contribuíram ao imaginário da feitiçaria impondo um específico fetichismo do dinheiro, da mercadoria e do corpo. Os rumores de banquetes em que missionários e militares comiam as gazes sangrentas e os membros amputados dos africanos nas enfermarias (Beneduce 2010) permitiram também enfrentar o trauma dos desaparecimentos e da escravidão.

Outros exemplos etnográficos mostram como o poder do outro pode ser explicado e manipulado por meio da incorporação: antropofagia ritual na Amazônia (Fausto 1997, 2002); emprego de imagens do colonizador em rituais terapêuticos pelos xamãs cuna na Colômbia (Taussig 1993); e cultos de possessão na África Ocidental (Rouch 1955).

A feitiçaria é um discurso que permite lidar com novas formas de poder e de desigualdade, num contexto de desordem epistemológica diante das rápidas mudanças e daquilo que Joseph Tonda (2005) chama de "violência do imaginário", que produz uma extraordinária "fusão-confusão de todas as formas de violência possíveis" e conecta os planos material, simbólico e imaginário.

A pretensão de ordem e racionalidade do Estado pós-colonial choca-se com as crenças sobre feitiçaria e mostra a dificuldade de regulamentá-las e dominá-las, como sobressai nos êxitos das diferentes atitudes perante as demandas da população de condenar os feiticeiros, por exemplo, na República dos Camarões e na África do Sul.

Em Camarões, o Estado tentou conter e governamentalizar a feitiçaria, por meio do controle das acusações e das vinganças privadas e da burocratização dos tradi-praticiens $^{8}$ (Geschiere 1997, 2000), e atender às solicitações da população, com a legalização dos tradi-praticiens e a rotinização das acusações nos tribunais. Por outro lado, na África do Sul, o Estado pós-apartheid, na tentativa de afirmar uma imagem de modernidade e racionalidade, recusou-se em acolher os pedidos de justiça contra os feiticeiros. Em ambos os casos, a procura por ordem e racionalidade mostra suas falhas diante de algo fluido e incontrolável como a feitiçaria: a falência do Estado manifesta-se no aumento do medo do "mundo da noite" e nas suspeitas de envolvimentos de representantes do poder político e econômico na feitiçaria. De fato, a acumulação de riqueza e poder é, frequentemente, interpretada em termos mágicos; 
assim, acredita-se que os membros das elites e as pessoas que alcançam rapidamente o sucesso se sirvam dos feitiços mais novos e mais poderosos.

Uma forma de feitiçaria considerada particularmente poderosa faz uso de partes do corpo humano, usualmente amputados de pessoas em vida, levando a um comércio que supera as fronteiras nacionais. Acredita-se que as "medicinas" fabricadas permitam empossar-se da energia vital da vítima de uma maneira mais direta e eficaz.

Desse modo, as metáforas da comensalidade e da antropofagia produzem mais um fio no entrelaçamento entre poder, medo, violência e conflitos.

Como salienta Yengo:

De fato, ver que todos esses dirigentes africanos se envolvem com os "sacrifícios humanos", as mortes rituais especialmente ao momento do calendário eleitoral, faz aparecer a feitiçaria como a melhor postura discursiva que a ordem pós-colonial adota sobre si mesma, a encenação, na linhagem, do poder estadual africano na época da mundialização, onde abaixo de seu caráter arcaico, se revela consubstanciada no Estado moderno. (Yengo 2016:173-174).

O objetivo deste artigo é explorar a relação entre poder, riqueza, conflitos e violência (física, simbólica, do imaginário) colonial e pós-colonial por meio da metáfora do comer, em que se entrelaçam comensalidade, antropofagia e feitiçaria, expressando um imaginário que se constrói, renova e recria ao longo dos processos históricos, num jogo de espelhos entre tradição e modernidade, Estado e população, vida cotidiana e "mundo da noite", ataques mágicos, infortúnios e cura e que, mediante a desordem, o mistério e o terror, permite domesticar, entender e reagir à violência e às rápidas mudanças socioeconômicas.

A análise é realizada com base em uma revisão bibliográfica de pesquisas sobre diferentes países da África Subsaariana - com particular atenção à República dos Camarões, Congo, Ghana, Togo, África do Sul, Moçambique - e de estudos sobre antropofagia e a relação entre imaginário do oculto e violência colonial na América do Sul, de acordo com a ideia de que a comensalidade pode servir de chave interpretativa para diferentes fenômenos que estruturam a vida social, o imaginário e a história (narrada e incorporada).

O artigo é estruturado em quatro partes. Na primeira, analiso as imagens, centradas no corpo, no luxo e na comensalidade, que o Estado pós-colonial da República dos Camarões usa para confirmar o poder e torná-lo familiar e sagrado. Mostro sua recepção pela população e seu enraizamento na história e na cultura local, captando os nexos com a feitiçaria e o "imaginário do oculto". Na segunda parte, atingindo um material etnográfico vindo de diferentes contextos, aprofundo o significado da comensalidade e da antropofagia, mostrando sua força em explicar o poder e em incorporar a alteridade. Argumento como a história - em que a colonização e os 
processos de descolonização e modernização constituem marcos importantes - ajuda a compreender a força das imagens da comensalidade, da antropofagia e da feitiçaria em dar sentido ao poder e à violência. Na terceira parte, foco minha análise nas tentativas dos Estados pós-coloniais em enfrentar o aumento dos medos e das acusações de feitiçaria e seus resultados, concentrando-me em duas estratégias diferentes: a da República dos Camarões e a da África do Sul. Na quarta parte, explicito como a proliferação da feitiçaria acompanhou as mudanças políticas, sociais, econômicas e o processo de urbanização das últimas décadas. Analiso, enfim, uma forma particularmente poderosa e assustadora de feitiçaria, que usa partes do corpo humano e que faz coincidir incorporação do poder, violência e antropofagia.

\section{Poder e comensalidade nos Estados pós-coloniais}

Analisando o Estado e o poder na perspectiva de como se apresentam às pessoas comuns nas interações, nos discursos e nos encontros cotidianos, em diferentes contextos aparecem imagens que elaboram uma personalização, uma antropomorfização.

De fato, é por experiências e discursos cotidianos que o poder é confirmado, desconstruído, elaborado e remodelado na sua rotina, de acordo com um imaginário e uma linguagem criados e difundidos por seus representantes, pela mídia e pelas pessoas comuns, num processo em contínua tensão.

Mbembe (2006) mostra como na República dos Camarões (assim como em outros Estados da África Subsaariana, como o Togo e o Congo) a elite política e a população produzem conhecimento sobre o Estado e interpretam o regime de dominação e de violência por meio de imagens barrocas e grotescas, que remetem ao tema da comensalidade e que se focalizam no corpo e nas suas funções biológicas (em particular, a digestiva e a sexual).

Alusões à boca, ao pênis e à barriga são centrais na estética construída pelo poder e ao redor do poder nos Estados pós-coloniais africanos:

[...] O comando na pós-colônia possui um marcado gosto para a vida lasciva. A respeito disso, cerimônias e festividades são os dois veículoschave para condescender com o gosto. Mas a linguagem de suas formas e de seus símbolos é, acima de tudo, a boca, o pênis, e o ventre. [...] À boca, ao pênis e ao ventre - como princípios estruturantes, assim como objetos de atos verbais e gargalhada popular -, de fato, são atribuídos significados múltiplos e ambivalentes. São invocados para comentar sobre vários aspectos da vida social - a relação com o tempo, o jogo e o prazer. Em breve, são mobilizados por quem quer fazer uma afirmação acerca da existência humana e da ordenação da sociedade, da morte, da desigualdade, ou da "feitiçaria". Nesse sentido, servem como referências ou metáforas críticas na produção da política na pós-colônia. (Mbembe 2006:384). 
O imaginário e a figuração (nos termos de Norbert Elias) baseados na riqueza e no luxo ostentados pelos representantes do poder político e econômico em países marcados pela fome e pela escassez de recursos estão na base do sistema de desigualdades políticas, sociais e econômicas, das dinâmicas de construção, reforço, proteção e naturalização do carisma dos grupos dominantes, e da separação, da estigmatização e do menosprezo dos grupos "dominados". Com efeito, segundo Elias, o conceito de carisma deve ser empregado em acoplamento com seu oposto, "o outro lado da moeda, como o menosprezo coletivo, o ostracismo, a desgraça e a difamação" (Elias 2009:74). O carisma se constrói na inter-relação com os dominados, mediante ações, performances, símbolos, imagens, imaginários, relações de interdependência e influência recíproca de forma concreta e cotidiana. Para o autor (Elias 1994), de fato, pessoas e grupos entram em jogo nesse processo com suas características biológicas, culturais, sociais, psicológicas num contexto histórico, social e cultural específico. A construção de poder é acompanhada pela imposição de um marco distintivo, de uma barreira que separa os grupos dominantes dos dominados, e por um reforço da relação entre carisma e desgraça, que acaba naturalizando diferenças, identidades e desigualdades.

O Estado africano pós-colonial, chegando às pessoas por intermédio de uma representação tangível, real, doméstica, fundada na cultura popular, atinge o imaginário, constrói e afirma seu carisma, se torna um simulacro, um ídolo, um "fetiche", e estabelece uma intimidade criando obrigações com laços pessoais e simbólicos: "Um feitiço é, entre outras coisas, um objeto que aspira pela sacralização; requer poder e tenta manter uma relação íntima e próxima com aqueles que o possuem" (Mbembe 2006:388).

E acrescenta Mbembe:

Na pós-colônia, o comando procura institucionalizar-se, com o intuito de alcançar legitimação e hegemonia [busca hegemônica], nos termos de um feitiço. Os sinais, o vocabulário, e as narrativas que produz não são destinados a tornar-se objeto de representação. São oficialmente investidos com um excesso de significado que não é negociável, e a que é oficialmente proibido transgredir. Para assegurar que tal transgressão não aconteça de fato, os campeões do poder do Estado inventam uma inteira constelação de ideias; selecionam um conjunto separado de repertório cultural e conceitos poderosamente evocativos; mas recorrem também à aplicação sistemática da dor, já que o objetivo principal é a produção de um imaginário. (Mbembe 2006:382).

Exatamente por ser sacralizado, o Estado pune com muita firmeza os atos de profanação da sua imagem, como mostrado por Mbembe (2006) em sua análise das punições corporais infligidas a pessoas que não prestaram as "devidas" homenagens aos representantes e aos símbolos do poder estadual.

Jean-François Bayart (1989) introduziu a expressão "política do ventre" ("belly politics"), termo usado pelos mesmos camaronenses e baseado na cultura 
local, para indicar a chave de compreensão do sistema político pós-colonial. Centra-se na trama entre a luta pelo poder e a luta pelas riquezas e numa concepção do Estado como acesso a bens, domínio, privilégios e prestígio, o que produz um "ethos de enriquecimento pessoal". O alcance de posições de poder significa também a possibilidade de ocupar "posições de predação" e de dominação, que permitem a apropriação direta e pessoal dos principais meios de produção e de troca. Todavia, o gasto, o luxo e o excesso exibidos pelos Estados pós-coloniais não se explicam com a racionalidade, a utilidade, a preservação da vida e a produção, mas se caracterizam pela perda, constituindo "despesas" improdutivas, nos termos de Georges Bataille (2005):

[as] despesas ditas improdutivas: o luxo, os lutos, as guerras, os cultos, as construções de monumentos suntuários, os jogos, os espetáculos, as artes, a atividade sexual perversa (quer dizer desviada da finalidade genital) representam outras tantas atividades que, pelo menos nas condições primitivas, têm o seu fim em si próprias. Ora, é necessário reservar o nome de despesa a estas formas improdutivas, excluindo todos os modos de consumo que servem de meio termo à produção. Embora seja sempre possível oporem-se umas às outras as diversas formas enumeradas, elas constituem um conjunto caracterizado pelo fato de em cada caso a tônica ser colocada na perda que deve ser a maior possível para que a atividade tome o seu verdadeiro sentido. (Bataille 2005:30-31).

Segundo Bataille, o ponto culminante da realização humana é o consumir, e não o produzir; o despender, e não o conservar; o destruir, e não o construir.

A legitimidade e o valor da despesa improdutiva dos Estados pós-coloniais são construídos socialmente, já que integram um sistema econômico e um sistema simbólico, que se retroalimentam reciprocamente.

De fato, a "política do ventre" é também a manifestação das necessidades de uma sobrevivência precária e o produto de representações culturais que são fruto da história. Yengo (2016) observa que:

Já que, se se chegou a falar da "política do ventre" para caracterizar a governamentalidade dessas sociedades, é porque na alquimia do desejo que atravessa sua história e roga todo seu espaço social, a grilagem e a predação desempenham bem a função de ação pública e de estratégia num sistema de valores onde os papéis principais são devolvidos ao dinheiro e às mercadorias, essas coisas dos Brancos. (Yengo 2016:28).

As lógicas locais do ventre, da linhagem e do poder se apresentam ainda como reacomodações tensas numa nova ordem social, que geram extermínio, poder de 
morte e conflitos a vários níveis da sociedade e que estão em continuidade com uma história marcada por diferentes formas de violência e conflitos.

É possível traçar uma continuidade entre as dinâmicas do poder nos Estados pós-coloniais com a dominação colonial, cuja função principal não foi somente produzir corpos economicamente produtivos e proveitosos, mas construir o sujeito colonial enquanto dócil, domesticado, desumanizado, infantilizado, oprimido por mecanismos de coerção ${ }^{9}$, em que a violência aparecia como discurso rotineiro, simbólico, e a desigualdade e a opressão foram racionalizadas ${ }^{10}$.

O governo pós-colonial, observa Mbembe (2006), vai além da violência para produzir corpos sujeitados à lógica econômica: em Camarões, o Estado mostra sua vontade de obrigar os indivíduos a participarem da sua espetacularidade no dia a dia, em cerimônias públicas, hinos, homenagens, tentando submetê-los à sua lógica e à sua epistemologia.

O governo alcança o luxo e o excesso por meio da extração das riquezas da população, com a cobrança de vários tipos de taxas e a exploração de seu trabalho, cuja finalidade, além de tornar a população economicamente produtiva, é torná-la dócil. O resultado é um desempoderamento (termo que remete a um sentido material e que se serve da linguagem da feitiçaria) da população pelo poder estadual, que lhe suga o sangue, como evidenciado por Roberto Beneduce (2010) no caso dos Camarões, em analogia à interpretação do poder colonial e da imagem do vampiro na Colômbia proposta por Michael Taussig (1987).

Em forma análoga à análise de Michel de Certeau (1998) sobre as lutas em Pernambuco, estado do Nordeste do Brasil, as estratégias do poder político e militar têm como contrapartida as táticas do povo, narrativas e jogos, baseadas em subterfúgios, simulações, enganos, que permitem manipular as narrativas do poder de formas distintas e antagônicas. O público, obrigado a participar ficando em pé, batendo as mãos, cantando ou dançando, recebe os discursos e as performances oficiais para depois os reverter de forma subterrânea, escondida, por meio da gargalhada, de jogos de palavras, piadas e fofocas, que mostram seu aspecto obsceno e grotesco. Leva à tona a vulgaridade que permeia a apresentação barroca do Estado pós-colonial, mediante referências aos orifícios e às funções biológicas (excesso de comida e de bebida, evacuação de fezes, desejo sexual incontrolável, luxo).

Jogos e narrativas representam uma resposta prática, um know-how que pode providenciar um meio para jogar e arruinar o mesmo jogo, um espaço utópico em que pode surgir uma esperança de outras possibilidades e "microrresistências" que proporcionam "microliberdades".

A subversão e a ridicularização do discurso oficial representam também a reivindicação de uma "carnavalização" do mundo como prática de resistência e transformação social perante o discurso dominante, como ressalta Raúl Ernesto García Rodríguez (2013), com base na análise do conceito de "carnaval" de Michail Bakhtin. $\mathrm{O}$ autor afirma que: 
O recurso à parodia e o exercício de subversão do texto oficial ou solene, assim como a inserção coletiva da gargalhada [servem] para inaugurar uma existência alternativa ou "segunda existência", em virtude da qual se contradiz qualquer congruência identitária vinculada à reiteração de um regime discursivo associado às relações de poder. Penso então a carnavalização como âmbito gerador de formas específicas de linguagem e comunicação que, por meio também da corporalidade grotesca e do mascaramento, transgredem as pautas estabelecidas do comportamento funcional e organizado e abrem, portanto, um caminho para outras práticas de liberdade e de produção de subjetividade. (Rodríguez 2013:121).

A população, ao cumprir os mandatos prescritos nas performances oficiais do poder, converte sua participação em práticas de liberdade, escapa dos significados impostos e da ordem vigente, transgrede a conduta prescrita e funcional à manutenção das estruturas de poder criando uma polifonia, construindo um jogo, um "carnaval" no sentido de Bakhtin (1987). Bakhtin aponta para o princípio cômico, as formas e os símbolos da carnavalização e do "humor do povo" (em alusão a François Rabelais) como meios de construção de um "mundo ao avesso", contraditório, com permutações do alto e baixo, servindo-se de diversas formas de paródias, inversões de sentidos, degradações e profanações das normas sociais e das hierarquias de poder. Os elementos carnavalescos são norteados por um princípio "vital-material-corporal-concreto" (Rodríguez 2013:126) e se expressam em "práticas de liberdade incompletas e absurdas, no contato vivo, material e sensível" (Rodríguez 2013:125), que dialogam com e modificam o cotidiano mediante um rebaixamento que absorve e renova o mundo.

De fato, a imagem de um corpo que defeca abundantemente após um luxuoso banquete pelo qual a população ridiculariza as imagens do poder remete à ideia de "corpo aberto", que, no imaginário popular, se opõe ao corpo "fechado", "blindado", protegido dos ataques místicos. Consequentemente, o jogo entre as representações oficiais do Estado e sua paródia liga o explícito e o implícito e resulta na remodelação das relações de poder num campo heterogêneo e variável de conflitos e alianças e num esvaziamento do poder por dentro, transformando as pessoas "sem poder" (expressão que remete à feitiçaria), "zombificadas", e produzindo imagens que representam a violência na sua forma mais radical e desumanizante.

Como observa Mbembe (2006:395): "A forma em que o explícito e o implícito são entrelaçados, e como as práticas daqueles que comandam e daqueles que são supostos obedecer são tão imbricados que se tornam sem poder. Já que são exatamente as situações de impotência [impouvoir] que são as situações de violência por excelência”.

A comensalidade e a feitiçaria fornecem um repertório de imagens poderosas que permeiam a vida social, operam para a construção da cosmopolítica, da noção de pessoa e permitem dar um sentido ao poder, à violência e às mudanças históricas, que, consequentemente, podem ser processados para se instalarem na sociedade 
de forma ressignificada e oferecer possibilidades de sobrevivência. Mas, por outro lado, se reforçam as crenças no mundo do invisível, que continua a reproduzir-se e a expandir-se, aparecendo em formas mais poderosas e assustadoras, que afetam todos os níveis da vida social e que aumentam o medo. Medo de ser vítima de ataques místicos, medo de ser acusado de ser o mandante ou o executor de um ato mágico, após um adoecimento ou uma morte, medo de ser vítima de mutilações e homicídios voltados a enriquecer "medicinas" e feitiços da força vital humana. As relações de poder que permeiam a sociedade em vários níveis acabam reproduzindo e fortalecendo um imaginário que se infiltra em todos os espaços da vida social e assusta todos.

\section{Antropofagia como explicação e incorporação do poder do outro}

A força das metáforas da comensalidade e do consumo (de comida, de corpos e de energia vital) para representar o poder pós-colonial está em continuidade com as tradições locais sobre feitiçaria, e com os registros criados, empregados e enriquecidos a fim de explicar e dar sentido ao poder colonial.

A administração colonial, junto às missões cristãs (que controlavam a saúde e a educação), tentou estruturar os corpos, as mentes e o imaginário dos africanos suprimindo os rituais e as formas de organização social pré-existentes e produzindo um conjunto de imagens, símbolos, modelos de ação e formas de classificação do universo e de redistribuição do poder.

Como observa Yengo (2016:109), a lógica do poder colonial visava levar as pessoas sujeitas à submissão de seus objetivos, servindo-se da força, da opressão e da atração pelos objetos trazidos: "Ampliação da lógica da mercadoria a todos os aspectos da atividade social e construção do Estado sobre o medo e o arbítrio, negação de seus próprios valores e produção de um sujeito moral como empreendedor da própria submissão" (Yengo 2016:109).

Nas colônias, conviveram biopolíticas e necropolíticas, preocupações sanitárias, torturas e poderes de morte, num entrelaçamento entre o econômico, o biológico e o político numa atmosfera de terror. $\mathrm{O}$ Estado colonial aplicava a soberania à vida em sua forma mais extrema, no poder de decidir quem podia viver e quem era deixado ou feito morrer, como ressaltado por Mbembe (2018) com o conceito de necropolítica. Típica do governo colonial é a aplicação diferencial do direito e da humanidade, entre "homem civil" e "selvagem", colocando os colonizados num espaço intermediário entre a condição de "pessoa" e aquela de "objeto".

Michel Foucault ressalta a dissociação dos poderes do corpo na disciplina colonial, que contribuiu para plasmar o imaginário local sobre a feitiçaria, baseado na força, na energia e no poder:

A disciplina aumenta as forças do corpo (em termos econômicos de utilidade) e diminui essas mesmas forças (em termos políticos de obediência). 
Numa palavra: ela dissocia o poder do corpo; faz dele por um lado uma "aptidão," uma "capacidade" que ela procura aumentar; e inverte por outro lado a energia, a potência que poderia resultar disso, e faz dela uma relação de sujeição estrita. (Foucault 1987:119).

A incerteza da violência, a vulnerabilidade, a desorientação diante do colonialismo e da absurdidade das práticas de sujeitamento ${ }^{11}$ encontraram uma possibilidade de compreensão, negociação, remodelação e resistência nas teorias locais sobre o mundo invisível, amarrando o dia e a noite, o colonizador e o colonizado numa mesma rede de significados. Produziu-se, dessa forma, uma simbologia da comensalidade e do consumo, empregada como instrumento para pensar o poder e traduzir numa linguagem conhecida - a da feitiçaria - a absurdidade da violência colonial ${ }^{12}$.

O imaginário, expresso nas configurações do mal, do mundo do invisível e do saber médico tradicional, tornou-se lugar de conflito, que os colonizadores e, sucessivamente, os governos pós-coloniais tentaram dominar, mas foi, ao mesmo tempo, a fonte caótica que permitiu estratégias de oposição, mascaramento e resistência.

Como salienta Beneduce (2010), as acusações a colonizadores e missionários de desumanidade e as fofocas sobre ritos macabros foram atribuições de potência e de força, propondo códigos e símbolos diferentes e antagônicos. As imagens de banquetes canibalísticos e a feitiçaria mostram, portanto, uma indocilidade, uma resistência epistemológica que contrastava a lógica da colônia, que tentou apresentar-se como paternalista, científica, humanitária e civilizadora.

Por exemplo, os mpangwé, que habitavam a floresta dos Camarões, eram considerados canibais, mas as representações sobre o comer, o canibalismo e a magia começaram a aparecer também nos discursos e nas preocupações das populações locais, em sua tentativa de encontrar uma forma para falar do poder e da violência do colonizador. Beneduce (2010) ressalta que os africanos acreditavam que os brancos (na figura dos padres que administravam os hospitais das missões) comessem as pessoas, sendo associados a panteras ou a feiticeiros de retorno da morte. A busca de ajuda no hospital era evitada, uma vez que se acreditava que o padre comesse os membros amputados e as gazes usadas para tratar as feridas.

A imagem do vampiro (de origem europeia e depois englobado no imaginário local) somou-se ao repertório tradicional de símbolos de poder, violência e cura numa forma mais real e menos imaginativa, ajudando a pensar as operações médicas relativas à circulação do sangue e aos líquidos biológicos. De forma análoga, a diminuição de fertilidade ${ }^{13}$, que se seguiu à colonização, foi interpretada como consequência da diminuição da energia vital, que estava sendo sugada pelos brancos.

Esses imaginários começaram a incluir também acusações a africanos como pertencentes a associações secretas que capturavam e vendiam homens e mulheres para serem levados à Europa ou a outros lugares, e, ainda, acusações de injeções que transformavam as pessoas em vacas para serem comidas. Buscava-se, dessa forma, 
domesticar e tornar compreensível o drama da escravidão e do desaparecimento das pessoas, no que colaborava uma parte da população local. Nos Grassfields (Camarões ocidentais), foram personagens locais, muitas vezes pertencentes ao mesmo grupo familiar das vítimas, que organizavam o rapto e a venda dos escravos.

Esses acontecimentos nutriram não somente o imaginário acerca do canibalismo e do vampirismo, mas também o tema da antropofagia fetichista endofamiliar, ainda muito forte na África: as vítimas seriam devoradas invisivelmente no interior de sua família, a fim de adquirir poder pessoal e riqueza, ou emigrar.

De modo análogo, Taussig (1987) mostra como as representações do poder colonial e do capitalismo ligadas à produção de borracha na Colômbia foram construídas por meio de uma política de terror, em que a violência e a tortura apareceram como uma finalidade em si mesma. $\mathrm{O}$ autor apresenta esse espaço de medo e desordem mediante a análise do imaginário e dos contos que tentaram dar um significado às atrocidades, representando de forma alucinatória o fetichismo da dívida pessoal que transformava as pessoas em coisas e associava o espaço da morte à escravidão.

O trabalho de fabulação que construiu a imagem de um índio selvagem e viciado em canibalismo, de um lado, serviu como justificativa para a crueldade dos colonizadores e, de outro, forneceu uma base para imagens construídas acerca dos brancos, identificados com o diabo ou com vampiros que sugavam o sangue dos indígenas. Os contos produzidos viabilizavam o terror num jogo de espelhos e mostravam uma dialética entre a cultura católica (que forneceu a imagem do diabo) e a indígena (que considerava o canibalismo uma forma de empossar-se da energia vital alheia).

O diabo representa um símbolo importante na história política e econômica e está na base do imaginário, cheio de terror e de desejo, construído acima do "fetichismo da mercadoria"14 nas plantações de cana-de-açúcar da Colômbia e nas minas da Bolívia. Seu papel no folclore e no ritual sobressai no pacto feito com ele para obter - em troca da própria alma - riqueza e produtividade, mas que, no final, deixa lugar à morte, à improdutividade, à destruição e ao desespero.

Comer significa apropriar-se do poder do outro num sentido espiritual, como expresso na feitiçaria, e, num sentido material, de acordo com Carlos Fausto (2002:7): "um consumo voltado para o desenvolvimento das capacidades subjetivas da pessoa", como sobressai na antropofagia ritual, na guerra, na caça e no xamanismo dos indígenas tupinambá.

O autor articula a "predação" no exterior e a alteridade à produção ritual do interior, expressando-as com o conceito de "predação familiarizante": os inimigos eram capturados e transformados em parentes, para proceder depois a um ritual de "inimização", que precedia o banquete em que ocorria a partilha da carne (de que não participava a pessoa que matou a vítima). Dessa forma, afirmavam-se e produziam-se relações no interior das unidades sociopolíticas.

$\mathrm{O}$ ato de "comer algo ou alguém, de qual maneira e com quem" atua num processo de transformação que conduz à identificação. 
A predação familiarizante caracterizava tanto a operação de domesticação da vítima humana na guerra quanto a da vítima animal no xamanismo. Os xamãs capturavam espíritos de bichos, comiam jaguares e outros animais, usualmente tabus, e os guerreiros matavam inimigos com a finalidade de estabelecer laços particulares familiarizando - então controlando - a alteridade. Essas relações eram concebidas e expressas em termos de parentesco: pai/filho ou senhor/xerimbabo (palavra que denota a filiação adotiva). Apropriavam-se da subjetividade, de habilidades que pertenciam ao outro (humano ou animal), que virava parte integrante da pessoa do predador conferindo-lhe capacidades oníricas, fertilidade, força, coragem, cantos para os rituais, habilidades na caça e vida longa: "Ao oferecer um canto, o inimigo dá uma parte de si mesmo para o sonhador, sua parte-jaguar" (Fausto 2002:28-29).

No entanto, no processo de incorporação da alteridade, xamãs e guerreiros nunca podiam controlar inteiramente seus xerimbabos, devendo garantir a condição subjetiva do outro e correndo o risco de perder a sua. É nessa alteridade, carregada de perigo, que residia o poder de cura do xamã.

Por outro lado, os não humanos (animais ou espíritos) podiam capturar os humanos, seduzindo-os e/ou predando-os, para transformá-los em membros da sua comunidade, já que a doença e a morte eram consequência da aceitação da comida ou da bebida oferecida pelos mortos ou pelos animais.

As populações locais inseriram o encontro colonial dentro de sua interpretação epistemológica da alteridade e da antropofagia, domesticando, familiarizando e incorporando os discursos dos missionários e os bens introduzidos pelos conquistadores. Fausto (1992) observa que, na cosmologia tupinambá, o colonizador foi associado aos xamãs que andavam curando, profetizando e falando de uma "terra sem mal", de abundância e imortalidade.

A tentativa de incorporar o poder do outro é evidente também nas práticas dos xamãs cunas (Taussig 1993), que construíam seu poder de cura de forma criativa com um excesso de significado, misturando as imagens de selvageria atrelada aos índios pelos europeus com figurinhas de madeira representantes dos colonizadores e da cultura pop ocidental, cuja força era "domesticada" e incorporada. Procediam com a fabricação de imagens de terror, morte e selvageria, em que a desordem era manipulada e empregada em sua força criativa, em ações ao mesmo tempo alucinatórias, miméticas e políticas.

Em forma análoga, na África Subsaariana, a dinâmica entre violência, poder e dominação, de um lado, e imagens do oculto, de outro, age nos dois sentidos: a feitiçaria serve como explicação do "poder dos brancos" e incorpora imagens vindas do mundo colonial para reforçar-se e oferecer respostas a novas formas de sofrimento. Por exemplo, uma linguagem de guerra é usada para definir a luta do tradi-praticien como herói solitário contra o mal, e no ritual de blindagem (termo de origem militar) no qual o corpo é fechado, protegido contra os ataques místicos. A feitiçaria - em paralelo ao que acontece com os cultos de possessão (Beneduce 2002; Rouch 1955 ${ }^{15}$ ) - 
incorpora e ressignifica o poder do colonizador, por meio de técnicas miméticas, símbolos e objetos. A feitiçaria e a lógica antropofágica representam também elementos constitutivos e organizadores das relações sociais, do poder, da noção de pessoa e da cosmopolítica, num espaço movediço e manipulável, em que a desordem é geradora de novas possibilidades, novos imaginários e novas lógicas.

Um exemplo significativo é proposto por Beneduce (2010), ao analisar a nova figura de tradi-praticien que se apresenta nos Camarões e nas grandes cidades africanas: sua imagem e força são criadas com base em elementos heterogêneos que se misturam, se cruzam e encontram seu lugar numa bricolagem barroca, kitsch de objetos e instrumentos. Entre eles: ervas, elementos medicinais tradicionais, aparelhos médicos ocidentais (usualmente usados como "fetiches", dotados de força por seu valor simbólico de modernidade e tecnologia e pela proveniência ocidental), símbolos de poder e prestígio para os ocidentais e os africanos, emblemas de diferentes religiões, objetos de consumo, imagens de guerra, numa "pretensão de saber total e ânsia de identidade" (Beneduce 2010:183).

A acumulação caótica da qual surge a terapia do nganga, assim como do xamã cuna, revela as potencialidades criativas, performativas e terapêuticas da desordem, produtora de novos significados e interpretações ao redor do sofrimento, e de novas possibilidades de organização da pessoa doente. A desordem, portanto, aparece como dimensão manipulável e entrelaçada nas práticas cotidianas, nas esferas do público e do privado, e na própria produção ou aniquilamento do parentesco.

\section{Resistência da feitiçaria à governamentalidade}

Em muitos Estados africanos, a proliferação da feitiçaria e do imaginário das forças invisíveis foi acompanhada por uma crescente demanda de justiça contra os feiticeiros, com respostas diferentes por parte do Estado. Todavia, a crença na feitiçaria parece escapar a todo esforço de "governamentalização"16, controle e racionalização e continua a proliferar-se e reforçar-se como imaginário e como realidade social organizadora dos poderes, das violências e da socialidade produzida nos diferentes contextos.

Governo, tribunais, pastores, padres, sacerdotes e empreendedores do mercado religioso participam da "governamentalidade da barriga" (Beneduce 2010:152), ou seja, do controle de materialidades, símbolos e imagens relacionados à nutrição, à acumulação, à vitória, ao sucesso, ao prestígio, aos ataques ou às mortes por feitiçaria. Medos e incertezas são transferidos no mundo do invisível, numa proliferação de discursos de que participam e nos quais se confrontam uma multiplicidade de agentes num entrelaçamento de alteridades e poderes situados que se reacomodam conforme interesses, estratégias e táticas heterogêneas.

Os missionários cristãos, atuando como empreendedores da saúde, introduziram as imagens do diabo e da possessão demoníaca para explicar a feitiçaria. Como 
salienta Yengo (2016:167): "O par feitiçaria/demônio se impõe, em consequência da Inquisição na Europa, em todo o reino do Kongo, desde a primeira cristianização e conversão dos reis kongo, que acompanha as campanhas de queima dos 'feitiços'."

Os movimentos sincréticos de caráter pentecostal do século XX, na África Central, continuam o empreendimento cristão de luta contra a feitiçaria e os feiticeiros, e oferecem meios terapêuticos contra a doença e o infortúnio (interpretados como ataque de espíritos malignos ou demônios) mediante a confissão, o descarrego e o exorcismo.

Em vários estados africanos, governos locais e organizações não governamentais foram protagonistas de tentativas de governamentalizar a terapia e a feitiçaria servindo-se de diferentes estratégias: projetos de promoção da medicina tradicional, burocratização da prática de tradi-praticien e controle das acusações de feitiçaria nos tribunais.

A consequência principal dessas intervenções, no plano político, foi o alargamento do território da governamentalidade, a potencialização das formas de ação do Estado e sua propagação a novos territórios e campos de ação.

Beneduce (2010) mostra como a medicina tradicional em Camarões está sofrendo um processo de "burocratização", que responde também a um pedido de legitimação dos mesmos ngangas, que devem confrontar-se no mercado da terapia com a medicina ocidental e com os pastores e as igrejas pentecostais.

A descrição de Beneduce (2010:200-213) do gabinete-laboratório de Emmanuel Patrice Bekono Meyong, presidente do Conseil des Promoteurs du Groupe Phyotobek's e promotor do projeto de desenvolvimento "Complexe de Plantes Médicinales Traditonelles Bek's-Cameroun”, mostra um duplo processo de racionalização dos saberes da medicina tradicional. Por um lado, a burocratização é expressa em documentos e no certificado de pertencimento a associações locais de tradi-thérapeutes; por outro, uma tentativa de trazer a racionalidade da medicina ocidental para sua prática de cura é manifesta no uso de um léxico "magicamente científico" na classificação das plantas e das doenças, e num escrito que tenta afastar a AIDS das interpretações místicas, ligando-a a aspectos sociais e econômicos e enquadrando-a numa visão científica e racional.

A incerteza classificatória e a produção barroca dos poderes terapêuticos se manifestam nas listas das competências dos tradi-praticiens (em que confluem atos heterogêneos e registros interpretativos e epistemológicos diferentes, como tratar doenças com a fitoterapia, produzir a chuva, fazer ganhar um jogo de futebol), mostrando, ao mesmo tempo, o esforço e a resistência dos saberes da medicina tradicional e do invisível a todas as tentativas de racionalização, burocratização e dominação, assim como sua intrínseca ambiguidade e dinamismo.

Os projetos de censo dos curandeiros, as classificações de seus conhecimentos e competências e o controle de suas práticas terapêuticas podem ser inscritos numa expressão da "governamentalidade", em que os tradi-praticiens se confrontam com 
formas de legitimidade e hierarquia impostas do exterior, que geram frequentemente suspeitas e conflitos. Em contrapartida, os mesmos tradi-praticiens fazem um uso estratégico da relação com as instituições públicas, por meio da incorporação de outros discursos e saberes (como o biomédico), da tentativa de burocratização de seus saberes, do oferecimento de "medicinas", amuletos e rituais desejáveis pelos representantes do poder (como aqueles que favorecem a acumulação de riquezas e poder, sucesso nas eleições, derrota de seus inimigos), intervenções nas mídias locais, propaganda de seus serviços, com a finalidade de ver reconhecida a própria identidade profissional e a própria competência, e ganhar meios de competição no mercado da saúde.

Mas as reivindicações de modernidade e racionalidade dos Estados pós-coloniais mostram seus limites ao enfrentar a feitiçaria e o imaginário do oculto, pois o Estado se revela inadequado a controlá-los e a governamentalizá-los, como é evidente em dois casos emblemáticos, que mostram duas atitudes opostas do Estado em face das demandas de justiça pela população nos casos de feitiçaria: a África do Sul e a República dos Camarões. Ambas as estratégias miravam a uma governamentalidade dos saberes da medicina tradicional e a uma legalização da vida cotidiana.

Como salienta Adam Asforth (2004), o governo sul-africano pós-apartheid procedeu no registro e na regulamentação dos curandeiros na National Traditional Healers Association, e avançava no reconhecimento e na implementação dos conhecimentos "alternativos" e das plantas medicinais. Ao mesmo tempo, os medos e as acusações de feitiçaria aumentaram nas cidades, cuja causa principal, segundo Asforth (2005), é a inveja, que se insinua nas relações sociais num contexto de rápidas mudanças e de aumento das desigualdades socioeconômicas.

Mas a nova democracia, em sua tentativa de modernidade e racionalidade, recusou-se em admitir publicamente a existência da feitiçaria e tornou-se, então, impossibilitada a regulamentá-la ou a proteger os cidadãos e a satisfazer seus pedidos de justiça na esfera pública. Dessa forma, o Estado deixou espaço à justiça privada e comunitária, para depois ter que perseguir quem dava caça aos feiticeiros ou cometia homicídios de vingança.

Tudo isso fez levantar acusações contra o Estado por favorecer os feiticeiros em lugar de proteger as vítimas e contribuiu para enfraquecer a legitimidade das suas instituições e reforçar a suspeita de que as mesmas elites políticas se serviam da feitiçaria para "comer" as pessoas a fim de obter mais poder e riqueza, pois, como observa Asforth (2004:162): "No paradigma da feitiçaria, a tendência é de assumir que a fonte secreta do poder, que se esconde abaixo das aparências, seja inerentemente malvada".

Também a interpretação da difusão da AIDS na África do Sul em termos biomédicos e as medidas preventivas mediante o controle do sexo mostram sua incapacidade em explicar e enfrentar uma doença que se tornou a principal causa de morte no país e representa uma catástrofe demográfica e uma tragédia humana, sobretudo entre a população negra. Didier Fassin (2007) observa como a AIDS, na África do Sul, representa, simultaneamente, uma crise sanitária e uma crise epistemológica, 
que podem ser entendidas somente pela análise das desigualdades socioeconômicas, da pobreza, das migrações das áreas rurais para as cidades e da história do país, marcada pela institucionalização da diferença racial e das violências da colonização e do apartheid. Na crise do discurso, intervêm a incapacidade de explicar a experiência da AIDS, uma pluralidade de acusações à população negra de promiscuidade sexual, de alcoolismo, de estupros a crianças e jovens (ligados à crença de que seria possível purificar-se por intermédio de relações sexuais com uma virgem) - acusações que têm como pano de fundo a introjeção da culpa nos indivíduos pelas missões cristãs durante a colonização, que promoviam um senso de responsabilidade individual pelo próprio destino e por comportamentos supostamente desviantes, e o sistema normativo dos médicos que atribuíam às doenças, antes a sífilis e depois a AIDS, um caráter moral -, e a suspeita do governo, da mídia e da opinião pública, que acusam os oponentes políticos, os ativistas das campanhas de prevenção da AIDS, as companhias farmacêuticas internacionais, os brancos e os ocidentais de tentarem incriminar a jovem democracia e reduzir a população negra.

Fassin ressalta que a doença não envolve somente um processo patológico que ataca o corpo físico, mas revela também uma verdade histórica que é incorporada nas narrativas e nos corpos individuais e sociais: a experiência histórica não é apenas intelectual, é igualmente uma experiência profundamente enraizada no corpo, na forma de feridas ainda abertas e de uma realidade ainda presente. $\mathrm{O}$ autor mostra como a culpa e a suspeita estão na base da experiência da doença na história da África do Sul, marcada pela violência do período colonial e do apartheid, pela segregação racial, pela exploração da população negra que levou a uma intensa migração das áreas rurais para as cidades, pelas desigualdades socioeconômicas (que determinam também uma desigual distribuição do risco de contágio e das possibilidades de tratamento, de informação e de uma morte digna), pela relação entre dominação racial e saúde pública (que inclui a descoberta, após o término do apartheid, de planos de extermínio da população negra com o uso de armas biológicas, incluindo a esterilização das mulheres e a AIDS).

Asforth (2004) mostra o choque entre racionalidade científica e imaginário do oculto, explorando como uma abordagem científica ocidental na luta contra a AIDS na África do Sul foi recusada e mal interpretada pela população, que considerava as campanhas do uso de preservativos (assim como aconteceu nas campanhas de vacinação em época colonial) como uma tentativa de controlar o crescimento da população negra - sendo a AIDS definida como "uma invenção americana para controlar o sexo" (Asforth 2004:145) - e de reforçar o domínio da população branca.

Segundo Asforth, a visão científica da AIDS chocou-se com a interpretação tradicional da doença e foi obrigada a ceder-lhe espaço, pois esta, mesmo reconhecendo a AIDS como vírus, preenchia o vazio existencial e cognitivo deixado pela ciência ao fornecer aquele surplus de explicação - como evidenciado por Edward Evans-Pritchard (1976), a feitiçaria responde às perguntas: "Por que aconteceu a 
mim?", "Por que agora?", "Por que a doença degenerou levando à morte?" - e uma esperança de cura, negada pela medicina ocidental, já que o enquadramento da doença no horizonte social do conflito e da intencionalidade humana deixa espaço para esperanças de intervenção e sobrevivência.

Os sintomas da AIDS se encaixavam numa forma tradicional de feitiçaria chamada de isidliso (definido também como veneno preto ou veneno africano), a indicar uma lenta consumação da vítima por um pequeno animal que a come de dentro para fora, enviado (usualmente por vizinhos ou membros da mesma família) por meio de ervas e outras substâncias colocadas na comida.

Mas podia acontecer também que as acusações de feitiçaria recaíssem sobre a mesma vítima, pois acredita-se que os efeitos de um ataque derrotado regressem ao mandante.

A interpretação da AIDS no horizonte simbólico da "luta mística" produzia um empoderamento das crenças na feitiçaria, que levou a duas consequências importantes: primeiro, um combate no mundo do invisível, que aumentou o medo na feitiçaria e o recurso aos tradi-praticiens - que são também considerados responsáveis pelos ataques às vítimas -; segundo, uma ação no plano social, procurando controlar as relações nas comunidades (para evitar a inveja e os conflitos).

Na República dos Camarões, Geschiere (1997) relata como a epistemologia das forças ocultas foi englobada na justiça pública, já que os juízes, ao enfrentar casos que envolvem a feitiçaria, se servem das perícias dos tradi-praticiens.

A partir dos anos 1980, como resposta ao aumento das demandas de justiça pela população e das acusações de feitiçaria na Província Oriental dos Camarões, os tribunais começaram a empregar o testemunho do nganga como prova final e a infligir penas muito severas às pessoas condenadas por feitiçaria. Mas a condena e a reclusão não resolvem o problema, tendo em vista que se acredita que, na prisão, os feiticeiros aumentem seus conhecimentos, poderes e periculosidade, ao encontrar outros colegas. A cadeia é também uma forma de contenção das vinganças, protegendo o acusado de seus acusadores, que iriam matá-lo se estivesse livre.

Geschiere (2000) mostra os limites da racionalização e da legalização em lidar com a feitiçaria, já que esses procedimentos revelam a incapacidade do sistema legal de encarar a ambiguidade - pois, em primeiro lugar, não é possível distinguir claramente quem cuida e defende e que pode participar como especialista nos tribunais daquele que ataca e mata, que aparece como acusado -, a fluidez da feitiçaria e a impossibilidade de entendê-la fora do seu discurso. Enfim, sobressai-se a falha na ação do Estado em controlar a feitiçaria, pois, observa Geschiere (2000:237): "O Estado moderno é lançado num terreno onde não é equipado para exercer seu controle".

De fato, seu reconhecimento como termo de acusação e as condenações reforçam a difusão da feitiçaria (como crença, discurso, imaginário e agência social), seu papel estruturante da cosmopolítica e da noção de pessoa (contendo e dialogando com os símbolos de poder e uma lógica antropofágica), da etiologia da doença e 
do infortúnio, das várias formas de violência, e sua capacidade de permitir elaborar a história e oferecer respostas criativas.

Também a presença do nganga nos tribunais atribui-lhe legitimidade perante a população, aumentando sua clientela, alimentando a força do discurso e do imaginário da feitiçaria e estimulando a criação de novas e mais poderosas magias.

Nos anos de 1980, consequentemente ao reconhecimento público dessa figura profissional, emergiu uma nova personalidade de nganga: em contraste com o segredo e a aparência de camponês dos curandeiros anteriores, apresenta-se como uma figura moderna, fala francês, ostenta uma educação ocidental, erudição científica e conhecimento de outras tradições esotéricas, enfatiza sua colaboração com o governo, divulga sua atividade com manifestos vistosos, toma iniciativa em acusações de feitiçaria e contribui, por conseguinte, para espalhar o medo.

Dessa forma, a tentativa de governamentalizar, controlar, racionalizar e eliminar a feitiçaria nos tribunais levou ao efeito contrário, aumentando a insegurança, o medo e a desordem e impelindo a procurar agentes de saúde e formas de justiça diferentes do Estado, como as emergentes igrejas neopentecostais (Geschiere 2000; Tonda 2001). A feitiçaria contribui, ainda, para modelar e remodelar de forma criativa a desordem e a pluralidade de lógicas culturais (centradas no poder, na violência, na feitiçaria e na comensalidade), conectando os planos material, simbólico e imaginário, em contextos caoticamente pluralistas, marcados por processos coloniais e experiências pós-coloniais de longa duração.

Mas, ressalta Beneduce (2010), se, de um lado, os juízes condenam a feitiçaria, de outro, eles mesmos visitam os ngangas, como fazem igualmente outros componentes da elite econômica e política, como se pode deduzir da presença de automóveis de luxo estacionadas na frente das casas de famosos tradi-praticiens.

\section{Feitiçaria, consumo e poder}

Nas emissoras radiofônicas e nos jornais populares da África Subsaariana ecoam frequentemente medos e desejos ligados à magia, à feitiçaria e à violência cotidiana das forças ocultas, por meio de notícias de mortes diabólicas, políticos acusados de participar de sociedades secretas, propagandas de "medicinas" milagrosas que asseguram sucesso, riqueza, amor e cura de todos os males, psicoses urbanas de abduções de crianças ou desmembramentos rituais de jovens mulheres, conflitos domésticos e de vizinhança.

A proliferação da feitiçaria - como recurso, termo de acusação, fonte de insegurança e agente estruturante da vida social - e do imaginário da comensalidade e da antropofagia se desenvolve em contextos de conexões dinâmicas locais e globais, do colonialismo e da descolonização, acompanhando as rápidas mudanças que investiram o continente africano nas últimas décadas: urbanização, educação, cristianismo, comércio inter-regional e internacional, mercantilização de objetos, homens e ideias 
(como apontado por Tonda 2005; Geschiere 1997, 2000). Geschiere (2000) observa que a feitiçaria se tornou parte integral da visão e da gestão da modernidade e que as novas e espantosas manifestações aparecem nos setores mais modernos da vida: recentes formas de empreendimento, serviços de saúde, esportes, política.

Tonda (2005) adiciona um aspecto ligado ao imaginário dos bens de consumo: a difusão da feitiçaria expressa e tenta controlar também a desorientação diante das novas formas de riqueza e do desejo de apropriar-se delas, além de permitir que se assuma a posição de consumidores - de órgãos humanos no plano invisível, e de poder, riqueza e mercadorias no plano material.

No Estado pós-colonial, a feitiçaria alimenta a vida política e, como ressalta James Fernandez (1961) a propósito do Gabon, a competição política procede em paralelo com a competição mágica, já que a criação e o desenvolvimento dos grandes partidos nacionais foram acompanhados por um aumento das sociedades dos feiticeiros.

As elites políticas e econômicas têm a possibilidade de permitir-se muitos luxos inacessíveis às pessoas comuns e o acesso à feitiçaria e às "medicinas" melhores, mais caras e mais novas.

Poder, violência, antropofagia e feitiçaria interligam-se em novas práticas mágicas consideradas particularmente poderosas, em que são usados órgãos e partes humanas (cabeças, línguas, lábios, orelhas, crânios, corações, mãos, pés, dedos, peitos, órgãos genitais etc.) para fabricar "medicinas", a serem esfregadas na pele, em feridas abertas, ingeridas ou empregadas para fabricar amuletos carregados de poderes mágicos. As partes humanas são escolhidas segundo o efeito desejado, na base dos poderes mágicos e da força vital que contêm ou das crenças populares: por exemplo, o pênis para aumentar a virilidade, e os genitais femininos, a fertilidade; o peito para favorecer o nascimento de uma criança; o cérebro para acrescer a inteligência.

Segundo o relato "Trafficking Body Parts in Mozambique and South Africa" da Liga Moçambicana de Direitos Humanos, publicado em 2008 - que denuncia o tráfego de partes humanas nas fronteiras entre África do Sul e Moçambique -, as crianças e os albinos são as vítimas preferidas dessas mutilações, pois acredita-se que possuam maior força e energia. Membros e órgãos são frequentemente amputados da pessoa em vida, deixando-a agonizante ou morta, já que se crê que os gritos e o sofrimento da vítima os carregam de maior força.

Para falar desses corpos mercantilizados, Tonda (2005:147) usa o termo "corpo-sexo," que é também o "corpo da potência que queremos adquirir fazendo em pedaços os corpos".

Mas o documento "Trafficking Body Parts in Mozambique and South Africa" (2008:40), além de sublinhar os ingentes custos dessas "medicinas," ressalta que:

Muitas vezes, a pessoa que procura a assistência do feiticeiro [witchdoctor] deve fazer sacrifícios importantes. As entrevistas mostraram que a pessoa, às vezes, deve sacrificar não somente dinheiro, mas membros 
da família, incluindo a própria esposa ou as próprias crianças. Como descreveu um informador (o marido ed.) é uma pessoa que matou a esposa e pegou suas partes do corpo para que seus negócios lhe trouxessem mais dinheiro.

Igualmente, as pessoas contratadas para fornecer órgãos frescos e ainda pulsantes, frequentemente, escolhem suas vítimas no interior do seu núcleo familiar, mostrando uma outra faceta do processo de "deparentélisation", termo que Tonda (2005) emprega para descrever as transformações da sociedade na África atual, caracterizada pela ruptura da solidariedade entre os membros da mesma linhagem e das gerações, personificadas nos enfants-sorciers ${ }^{17}$, nas crianças soldados e nas prostitutas tuée-tuée ${ }^{18}$.

As acusações no interior da mesma família são ligadas também à crença tradicional - atestada, por exemplo, por Geschiere (2000) em Camarões - de que, para iniciar-se na feitiçaria, precisa oferecer ao mestre um parente próximo. Yengo (2016) relata que, no Congo, mulheres empreendedoras, na maioria comerciantes, podem ser levadas a oferecer seus filhos em sacrifício para fazer prosperar seus negócios. Mas o autor observa que, no meio urbano, onde as relações se organizam ao redor de diferentes laços de agregação e solidariedade (o trabalho, a economia, a política, a religião, o lazer), a feitiçaria é reinstitucionalizada no nível da sociedade inteira, que é considerada como linhagem, e, por consequência, as vítimas da feitiçaria e das amputações voltadas a produzir medicinas podem ser escolhidas num meio social mais amplo.

Em relação aos enfants-sorciers, Yengo (2016) ressalta que a fome leva as crianças a aceitarem fora de sua família a comida, que pode estar contaminada. Durante a noite, em sonho, o feiticeiro visita a criança, desvelando que consumiu carne humana e, portanto, tornou-se feiticeiro. Para não adoecer ou morrer, a criança deve, então, devolver a comida recebida, ajudando o feiticeiro a "comer" (matar) uma pessoa de sua família.

Asforth (2005) observa que, na África do Sul, o medo de ser vítima de amputações e homicídios continua a espalhar-se entre a população, junto à "insegurança espiritual".

O tráfego de partes humanas a fins mágicos pode ser posto em paralelo com o comércio internacional de órgãos para transplantes analisado por Nancy Scheper -Hughes (2005): em ambos os casos, sobressaem uma mercantilização e uma "fetichização" do corpo humano - na busca pelo órgão saudável e poderoso -, a concepção da pessoa como máquina, portadora de órgãos e não como sujeito, a produção de margens e a discriminação das pessoas que são passíveis de se tornar vítimas de violência e de virar mercadoria.

Assim como o Estado sul-africano - na tentativa de mostrar uma imagem de modernidade e racionalidade - se recusa a satisfazer as demandas da população de justiça nos casos de feitiçaria, também no tráfego de partes humanas a legislação em Moçambique e na África do Sul mostra-se inadequada. De fato, o documento 
"Trafficking Body Parts in Mozambique and South Africa" relata que a lei é pensada tendo em consideração somente transplantes e transfusões de sangue em âmbito hospitalar, e não leva em conta as mutilações e os assassinatos finalizados para fornecer a matéria-prima para "medicinas mágicas".

\section{Considerações finais}

A estética e o imaginário centrados no corpo e nas suas funções digestivas perpassam de diferentes formas o poder nos Estados pós-coloniais africanos. As metáforas da comensalidade e da antropofagia são tão poderosas e eficazes em mostrar, explicar, confirmar ou esvaziar o poder por serem fundadas numa realidade de pobreza e precariedade e numa cultura específica. As formas tradicionais de feitiçaria e o imaginário do oculto evoluíram e se enriqueceram para enfrentar o trauma da colonização e das rápidas mudanças sociais, econômicas e políticas das últimas décadas.

Comer algo ou alguém e sugar-lhe a energia vital - a fim de crescer e aumentar a própria força - são imagens que serviram e continuam a servir na compreensão e na domesticação de eventos históricos traumáticos e das mudanças sociais.

O mundo do imaginário - pela sua ambiguidade e fluidez - por quanto seja (como afirmam Tonda [2005] e Geschiere [1997]) produtor de desordem social, se apresenta, ao mesmo tempo, como um poderoso instrumento para produzir uma ordem epistemológica, já que permite que as mudanças sejam rapidamente integradas e que qualquer evento e situação encontre explicação e possibilidade de reação (no plano social e no plano do invisível). Assim, as acusações de feitiçaria representam um discurso que ajuda a personalizar o capitalismo internacional nas figuras dos feiticeiros e das bruxas e de interpretar a predação dos recursos locais por meio de conceitos familiares, tais como a "despossessão" e a "impotência", como salienta Bernault (2006).

Mas, por outro lado, essas imagens alimentam também a desordem, o medo, a violência e os conflitos: com sua difusão e proliferação, a feitiçaria mostra uma autonomia e uma indocilidade perante toda tentativa de racionalização e de controle, aumentando a desordem e aparecendo nas cidades e nos setores mais modernos da vida (a política, o esporte, as novas formas de empreendimento e a educação).

Tonda (2005) interpreta esses processos como uma série fluida e complexa de relações de força, pois o poder envolve os corpos, as mentes, as emoções e o imaginário público. A feitiçaria é um caso de poder, mas de um poder desestruturado, em constante mudança, tendo como protagonistas uma multiplicidade de atores sociais.

Tonda (2005) usa a expressão "soberano moderno" para indicar a forma genérica do poder na África Central, a "potência hegemônica [que] instrui e ministra a relação com os corpos, as coisas e o poder na África Central" (Tonda 2005:7). O autor reúne nesse termo a política, o cristianismo, o dinheiro, as mercadorias, os "corpos-sexo" 19 , a feitiçaria, o Estado, a indicar um poder que se formou em situações de violência, ao longo da história da dominação colonial e pós-colonial, das missões, 
do capitalismo e da globalização. Elementos, acontecimentos e interações de diferentes momentos históricos encontram-se, misturam-se e concentram-se numa mesma contemporaneidade.

O soberano moderno estrutura a vida política, administrativa, econômica e religiosa e invade todos os âmbitos sociais, exercendo uma violência sobre os sujeitos e os corpos. Tonda define essa violência como "violência do imaginário", que se expressa na ruptura com as tradições e a ordem habitual das coisas e é exercida no contexto de desregulamentação socioeconômica e de "déparentalisation" (ruptura da autoridade tradicional e das relações familiares e de linhagem) nas grandes cidades africanas.

À "violência do imaginário", soma-se a "violência do fetichismo", fundada no reconhecimento da realidade do "mundo da noite", de presenças e poderes invisíveis que atuam sobre os corpos e assumem uma realidade social que borra as fronteiras entre o visível e o invisível, entre o dia e a noite. Para Tonda (2005), a "violência do imaginário" e a "violência do fetichismo" fundem-se e tornam-se indissociáveis num contexto de "desregulação do imaginário", de crise das relações e dos valores tradicionais, segundo diferentes modalidades, incluindo a materialização em violência física de entidades que fazem parte do imaginário ou do mundo invisível, e a violência exercida sobre os corpos e o imaginário por imagens e "fetiches".

Nesse contexto de tensão e violência, a feitiçaria ressignifica seu domínio, num processo de interpretação e de constituição da realidade social, organizando um campo heterogêneo e dinâmico de imaginários, conflitos e sociabilidades, e contribui para a produção de uma violência intrínseca, que se molda e remodela, de forma dinâmica e variável, no espaço público e privado, e que ressignifica as práticas cotidianas de uma diversidade de sujeitos, governantes, feiticeiros, grupos domésticos e de parentesco, súditos, entre outros. A violência assume uma materialidade e uma realidade ulterior nas mutilações e nos desmembramentos de crianças e adultos, cujas partes são comercializadas e empregadas para produzir "medicinas" consideradas particularmente poderosas.

Tonda (2005) ressalta o papel estruturante (do imaginário e da vida social) da violência e de um fetichismo, ao mesmo tempo, religioso, político, econômico e sexual. Este é regido por um imaginário paradigmático do corpo, que inclui diferentes aspectos: "política do ventre" (acesso a uma posição predatória mediante o poder político), corpo do poder (com seus excessos e luxúria, mas também na forma de "fetiche"), corpo-mercadoria (com partes separadas e mutiladas para produzir "medicinas" e amuletos), corpos modificados e vestidos para responder a certos padrões estéticos, "corpo-sexo".

\section{Referências Bibliográficas}

ASFORTH, Adam. (2004), "AIDS and Witchcraft in Post-Apartheid South Africa". In: V. Das; D. Poole (ed.). Anthropology in the Margins of the State. Santa Fé: School of American Research Press. 
ASFORTH, Adam. (2005), Witchcraft, Violence and Democracy in South Africa. Chicago: Chicago University Press.

BAKHTIN, Mikhail. (1987), A cultura popular na Idade Média e no renascimento: o contexto de François Rabelais. São Paulo: HUCITEC; Brasília: Editora da Universidade de Brasília.

BATAILLE, Georges. (2005), A parte maldita precedido de A noção de despesa. Lisboa: Fim de Século.

BAYART, Jean-François. (1989), L'État en Afrique. La politique du ventre. Paris: Fayard.

BENEDUCE, Roberto. (2002), Trance e possessione in Africa. Corpi, mimesi, storia. Torino: Bollati Boringhieri Ed.

BENEDUCE, Roberto. (2010), Corpi e saperi indocili. Guarigione, stregoneria e potere in Camerun. Torino: Bollati Boringhieri Ed.

BERNAULT, Florence. (2006), "Body, Power and Sacrifice in Equatorial Africa". Journal of African History, no 47: 207-39.

CERTEAU, Michel de. (1998), A invenção do cotidiano. 1. Artes de fazer. Petrópolis: Vozes.

COMAROFF, Jean; COMAROFF, John L. (1999), "Nations étrangères, zombies, immigrants et capitalisme millénaire". Bulletin du Codesria, no 3-4: 19-32.

ELIAS, Norbert. (1994), The Civilizing Process. Oxford: Blackwell.

ELIAS, Norbert. (2009), "Group Charisma and Group Disgrace”. In: R. Kilminster; S. Mennell (ed.). Essays. On Sociology and the Humanities, vol. III. Dublin: UCD Press.

EVANS-PRITCHARD, Eward E. (1976), Bruxaria, Oráculos e Magia entre os Azande. Rio de Janeiro: Jorge Zahar Editora.

FANON, Frantz. (1968), Os condenados da terra. Rio de Janeiro: Editora Civilização Brasileira.

FASSIN, Didier. (2007), When Bodies Remember. Experiences and Politics of AIDS on South Africa. Berkeley: University of California Press.

FAUSTO, Carlos. (1992), "Fragmentos de história e cultura tupinambá: da etnologia como instrumento crítico de conhecimento etno-histórico”. In: M. Carneiro da Cunha (ed.). História dos Índios no Brasil. São Paulo: Companhia das Letras.

FAUSTO, Carlos. (1997), A Dialética da Predação e Familiarização entre os Parakanã da Amazônia Oriental: Por uma Teoria da Guerra Ameríndia. Rio de Janeiro: Tese de Doutorado em Antropologia Social, Museu Nacional/UFRJ.

FAUSTO, Carlos. (2002), "Banquete de gente: comensalidade e canibalismo na Amazônia". Mana, vol. $8, \mathrm{n}^{\mathrm{o}} 2: 7-44$.

FERNANDEZ, James W. (1961), "Christian Acculturation and Fang Witchcraft”. Cahiers d'Etudes Africains, $\mathrm{n}^{\mathrm{o}}$ 6: 244-270.

FOUCAULT, Michel. (1987), Vigiar e Punir. Petrópolis: Vozes.

FOUCAULT, Michel. (1995), "O sujeito e o poder”. In: H. Dreyfus; P. Rabinow (ed.). Michel Foucault. Uma trajetória filosófica: para além do estruturalismo e da hermenêutica. Rio de Janeiro: Forense Universitária.

FOUCAULT, Michel. (2006), "Governamentality”. In: A. Sharma; A. Gupta (ed.). The Anthropology of the State: A Reader. Oxford: Blackwell Publishing.

GESCHIERE, Peter. (1997), The Modernity of Witchcraft: Politics and the Occult in Postcolonial Africa. Charlottesville: University of Virginia Press.

GESCHIERE, Peter. (2000), "Sorcellerie et modernité: retour sur une étrange complicité". Politique Africaine, no 79: 17-32.

HUMAN RIGHT LEAGUE MOZAMBIQUE. (2008), Trafficking body parts in Mozambique and South Africa. [S. 1.: s. n.].

MBEMBE, Achille. (2006), "The Banality of Power and the Aesthetics of Vulgarity in the Post Colony". In: A. Sharma; A. Gupta (ed.), The Anthropology of the State: A Reader. Oxford: Blackwell Publishing. MBEMBE, Achille. (2018), Necropolítica. São Paulo: n-1 edições.

MEYER, Birgit. (1999), Translating the Devil: religion and modernity among the Ewe in Ghana. Edimburgh: Edinburgh University Press for the International African Institute. (International African 
Library, 21).

RODRIGUEZ, Raúl Ernesto García. (2013), "La carnavalización del mundo como crítica: risa, acción, política y subjetividad en la vida social y en el hablar". Atheea Digital, vol. 13, nº 2: 121-130.

SCHEPER-HUGHES, Nancy. (2005), "The Last Commodity: Post Human Ethics and the Global Traffic in 'Fresh' Organs”. In: A. Ong; S. J. Collier (ed.), Global Assemblages: Technology, Politics and Ethics as Anthropological Problems. Malden: Blackwell Publishing.

TAUSSIG, Michael. (1980), The Devil and Commodity Fetichism in South America. Cape Hill: The University of North Carolina Press.

TAUSSIG, Michael. (1987), Shamanism, Colonialism, and the Wild Man: A Study in Terror and Healing. Chicago: University of Chicago Press.

TAUSSIG, Michel. (1993), Mimesis and Alterity: A Particular History of the Senses. New York: Routledge. TONDA, Joseph. (2001), "La syndrome du prophéte. Médecines Africaines et précarietés identitaires". Cahiers d'Etudes Africaines, no 161: 139-165.

TONDA, Joseph. (2005), Le souverain moderne. Le corps de pouvoir en Afrique Centrale (Congo, Gabon). Paris: Karthala.

YENGO, Patrice. (2000), "Survivre en Afrique ou la logique du zombie". In: Peut-on être vivant en Afrique?. Paris: PUF. (Forum Diderot).

YENGO, Patrice. (2016), Les mutations sorcières dans le bassin du Congo. Du ventre et de sa politique. Paris: Karthala.

\section{Filme consultado}

ROUCH, Jean. (1955), Les Maîtres Fous. França, 36 min.

\section{Notas}

1 O presente trabalho foi realizado com apoio da Coordenação de Aperfeiçoamento de Pessoal de Nível Superior Brasil (CAPES) - Código de Financiamento 001.

2 O termo "medicina" indica substâncias, carregadas de poderes mágicos, a serem engolidas, esfregadas no corpo ou em escarificações.

3 A feitiçaria se inscreve na dicotomia visível/invisível e na temporalidade dia/noite. O feiticeiro opera a noite, durante o sono, no mundo do invisível, mas os resultados de sua ação materializam-se no corpo e a doença os torna visíveis.

4 O termo "zombificação" indica uma nova forma de feitiçaria muito temida da África do Sul, a que se atribui a escravização dos mortos (Comaroff \& Comaroff 1999; Yengo 2000).

5 A substância feiticeira, $k u n d u$, na África Central, pode ser adquirida por hereditariedade ou por ingestão de carne humana.

6 A independência econômica dos mais jovens leva a acusações de feitiçaria entre diferentes gerações, segundo disputas sobre a redistribuição das novas riquezas.

7 Os brancos eram considerados possuidores de uma magia muito forte, a "magia dos brancos".

8 Tradi-praticien, witch-doctor, curandeiro, médico tradicional, nganga (e outros termos nativos, este último sendo de Camarões) indicam apenas aparentemente uma categoria diferente daquela de feiticeiro, distinguindo entre quem faz o bem ou o mal. A demonização das religiões e das práticas terapêuticas tradicionais por colonizadores e missionários, que produziram uma confusão epistemológica e linguística, como observado por Meyer (1999), contribuiu para a ambiguidade dos poderes místicos.

9 Como evidenciado por Michel Foucault (1995).

10 Como ressalta Frantz Fanon (1968).

11 O sujeitamento na colônia, como salienta Foucault (2006), foi ao mesmo tempo um processo de dominação e de construção do sujeito colonial. O biopoder exercitado sobre os corpos valia-se de técnicas que miravam a construir corpos dóceis, corpos-máquinas em vista da produtividade. Apropriava-se dos corpos (na escravidão) e 
os disciplinava numa ótica simultaneamente individualizante e totalizante: por um lado, cuidando dos detalhes da vida cotidiana (por meio das normas de higiene e da educação familiar nas missões); por outro, tendo em vista o conceito de população, que reduzia as pessoas a números e apresentava-se em forma de longas filas para as vacinas impostas e as campanhas pela saúde. Para serem apropriados, os indivíduos das colônias precisavam ser dóceis e úteis, mortificados, brutalizados, desumanizados, por meio da criação de uma atmosfera de terror, de uma desorientação epistemológica e de uma dimensão onírica, mágica.

12 No caso da Colômbia, uma análise do mesmo problema é apresentada por Taussig $(1980,1987)$.

13 A mesma acusação de tentar controlar a reprodução da população negra foi feita ao Estado pós-apartheid sul-africano em relação às campanhas de luta contra a AIDS por meio do incentivo ao uso de preservativo.

14 Termo que Taussig (1980), assim como Tonda (2005), usa inspirando-se na teoria do capitalismo de Marx.

15 O filme Les Maitres Fous (Os Mestres Loucos), de 1955, descreve o culto de possessão songhai dos Haukas (termo que significa "loucos"), que surgiu no Niger e chegou em Akkra com as migrações. Os espíritos recém-chegados no panteão songhai, os Haukas, representavam a tecnologia e as figuras do poder colonial (helicópteros, trens, enfermeiras, comandantes do exército, governadores coloniais). Com a possessão e a mimese, os Songhai podiam conhecer e apropriar-se simbolicamente do poder e da tecnologia dos colonizadores.

16 Michel Foucault (2006:142) introduziu o termo "governamentalidade" para definir um conjunto de estratégias de poder: "Com o termo 'governamentalidade' pretendo dizer três coisas [...]. Primeira coisa, o conjunto das instituições, procedimentos, análises e reflexões, os cálculos e as táticas que permitem exercitar esta forma específica e complexa de poder que tem como objetivo principal a população, como forma principal de entender a economia política, como instrumento técnico essencial os dispositivos de segurança. Além disso, por governamentalidade entendo a tendência, a linha de força que, em todo o Ocidente, não parou de conduzir, e faz muito tempo, em direção da preeminência sobre todos os outros daquele tipo de poder que pode-se chamar de 'governo': soberania, disciplina, [...] Enfim, com governamentalidade, acredito que deveria entender-se o processo, ou, melhor, o resultado do processo por meio do qual o Estado de justiça da Idade Média, transformado em [...] Estado administrativo, encontrou-se aos poucos 'governamentalizado"'.

17 Na década de 1990, nas cidades da África Central (da República Democrática do Congo até a Angola) apareceu o fenômeno das crianças feiticeiras. São crianças caçadas de sua casa por serem acusadas de atos de feitiçaria contra membros de sua família ou vizinhos; formam grupos que povoam as ruas das grandes cidades. Muitos deles são recrutados nas milícias das guerras civis, tornando-se crianças-soldados.

18 "Mortas que matam", sendo portadoras da AIDS.

19 O "corpo-sexo" (sobretudo o da mulher) indica o corpo em sua potência e força, que vira "fetiche". O soberano moderno, por meio do dinheiro, transforma o "corpo-sexo" em mercadoria a ser consumida, mas, ao mesmo tempo, permite que a mulher se liberte dos papéis familiares e sociais tradicionais.

Recebido em: 28/08/2018

Aprovado em: 17/08/2020

\section{Daniela Calvo* (dnlclv7@gmail.com)}

* Doutora em Ciências Sociais pelo Programa de Pós-Graduação em Ciências Sociais da Universidade do Estado do Rio de Janeiro (PPCIS/UERJ), Rio de Janeiro, RJ, Brasil; Membro do Núcleo de Estudos de Religião (NUER/UERJ). 


\section{Resumo:}

\section{Comensalidade e antropofagia como metáforas de poder, violência e conflitos na África Subsaariana ${ }^{1}$}

O objetivo deste artigo é analisar a comensalidade e a antropofagia como metáforas que ligam poder, conflitos, violência e feitiçaria na África Subsaariana com base na revisão bibliográfica. $\mathrm{O}$ imaginário da feitiçaria continua a proliferar-se em todos os setores da vida social e acompanha os processos de urbanização e modernização. A feitiçaria e as imagens de banquetes antropofágicos representam uma tentativa de explicar e domesticar eventos históricos traumáticos, tais quais a colonização e a escravidão, a urbanização e as rápidas mudanças sociais, econômicas e políticas, por meio de reacomodações criativas que envolvem cosmologia, noção de pessoa e relações sociais, mas favorecem, ao mesmo tempo, a propagação da violência e do medo.

Palavras-chave: Feitiçaria; Política do ventre; Estado pós-colonial; Violência; Mutilações

\section{Abstract:}

\section{Commensality and anthropophagy as metaphors of power, violence, and conflict in sub-Saharan Africa}

The aim of this paper is to explore commensality and anthropophagy as metaphors that connect power, conflict, violence and witchcraft in Sub-Saharan Africa, on the basis of a bibliographic review. The imagery of witchcraft continues to proliferate in all sectors of social life and accompanies the processes of urbanization and modernization. Witchcraft and images of anthropophagic banquets represent an attempt to explain and domesticate traumatic historical events, such as colonization and slavery, urbanization, and rapid social, economic. and political changes, through creative rearrangements that involve cosmology, notion of person and social relations, but they favour, at the same time, the propagation of violence and fear.

Keywords: Sorcery; Belly politics; Postcolonial State; Violence; Mutilations 
